\title{
3D MODELING AND VISUALIZATION OF ARCHITECTURE AND LANDSCAPE.
}

\author{
L. Corniello \\ University of Campania “Luigi Vanvitelli”, Department of Architecture and Industrial Design, Aversa, Italy \\ luigi.corniello@unicampania.it
}

KEY WORDS: Connection, Photogrammetry, Survey, Model, Documentation, Accessibility.

\begin{abstract}
:
The study presents the results of architectural and vegetation survey missions in the UNESCO site of Quinta da Regaleira in the city of Sintra, Portugal. The different types of connecting elements of the epigean and hypogean architectures in the Park are analysed through the disciplinary tools of architectural design. Surveys and models of some of the connecting elements are proposed for an understanding of the site and its subsequent protection and valorisation through digital documentation. Of great interest is the architectural and social relationship that the site establishes with the city of Sintra.

The survey of epigean architecture considered the following: the Casa da Renasceça, the Capela, the Cocheiras, the Estufa, the Oficina das Artes, the Loggia dos Pisoes, the Casa dos Ibis, the Torre da Regaleira, the Terraço dos Mundos Celestes and the Fonte da Abundância.

The survey of underground architecture considered the following architectures: the Gruta do Labirinto, the Gruta da Leda, the Lago da Cascata, the Gruta do Aquario, the Gruta do Oriente, the Portal dos Guardiães, the Poço Imperfeito and the Poço Iniziático.

The work constitutes a complete and accurate analysis, represented through technical drawings, in different scales, digital point clouds and 3D modelling for the visualisation of the architecture in the Quinta da Regaleira in Sintra.
\end{abstract}

\section{INTRODUCTION}

The research presents the results of the epigean and hypogean architectural survey activities in the UNESCO site of the Quinta da Regaleira in Sintra, a Portuguese city located inland, not far from the capital Lisbon. In the present excursus, we present, in particular, the studies carried out on the connection systems, that is, the transitions between the horizontal surfaces through the staircases. The relationship between the different floors of the building has been analysed in the following architectures in the Park: for the epigean systems, we include the spine and circular staircases in the Palácio, the spiral staircase of the Capela bell tower, the connecting staircases to the Loggia dos Pisoes, the double well staircase of the Torre da Regaleira and the complex systems of access to the towers of the Terraço dos Mundos Celestes. Particular attention has also been paid to the vertical connections of the underground architectures: the relationships between the surface rocks, the present water basin and the steep and narrow stairs leading to the Gruta do Labirinto, the aerial routes of the Lago da Cascata, and finally the helicoidal staircase of the Poço Imperfeito and the ponderous well staircase with pillars of the Poço Iniziático.

A common feature in these architectures is the function of the staircase as a condition of connection between surfaces through the elements of the risers, treads and landings, and as a fluid structure, as an architectural element capable of ascending towards Paradise or descending into Hell.

\section{THE HISTORICAL AND THE ARCHITECTURAL EVENTS}

In the late 19th century, a verdant hillside overlooking the Portuguese city of Sintra was purchased by the wealthy patron Antonio Augusto Carvalho Monteiro to build a farmhouse set in a majestic garden.

After an initial design by the architect Henry Lusseau, the client contacted the Italian architect Luigi Manini in 1898 to design the palace in a Neo-Manueline style, as well as some ancillary rooms such as a chapel and a stable.

Manini began a process of architectural modelling of the architecture and remodelling of the landscape through a series of drawings and plans for the entire park, which took more than a decade to complete. The project, carefully studied both in terms of nature and architectural requirements, highlights the predominance of Neo-Manueline and Renaissance styles with the representation of the microcosm. Paradise, represented by the epigean architecture, coexists with hell, materialised in the underground component of the park. With these scenarios, the representation of an initiatory journey is realised in which references to mythology, Virgilian epics, Dante's world and alchemy can be glimpsed.

The image and expressive freedom of architectural and vegetation structures in a context of a scenic complicity where a cultural ideology and the same curiosity about the past century prevails was recognised in Manini. An analysis of the aesthetic terms shows that the work takes up an eclectic language, a historicism tempered with a modern graphic style, oscillating between the weight of tradition and the desire to innovate.

The first design hypothesis depicts three buildings, the main Palace, the Chapel and the stables, with great graphic mastery in the design of the spaces and elevations, as well as some perspectives of considerable technical skill. Between the first project and the start of work in 1904, a series of technical and architectural changes were made, forcing the designer to adapt the reconfiguration hypothesis to the pre-existing structures, for the Palace, characterised by a simple volume with a rectangular base and two floors, which differed considerably from the architectural tastes of the owner and the client.

It was deemed necessary to draw up a new project with the addition of a tower body with a polygonal plan and a series of projections, buttresses, porticos and pinnacles to give the old architectural structure a plastic architectural dimension.

With the construction of the Palace, a process of creation of the complex surrounding park began, characterised by the natural slope of the hill and epigeal architectural complexes, such as the 
Casa da Renasceça, the Capela, the Cocheiras, the Estufa, the Oficina das Artes, the Loggia dos Pisoes, the Casa dos Ibis, the Torre da Regaleira, the Terraço dos Mundos Celestes, the Fonte da Abundância, and hypogea, such as the Gruta do Labirinto, the Gruta da Leda, the Lago da Cascata, the Gruta do Aquario, the Gruta do Oriente, the Portal dos Guardiães, the Poço Imperfeito and the Poço Iniziático.

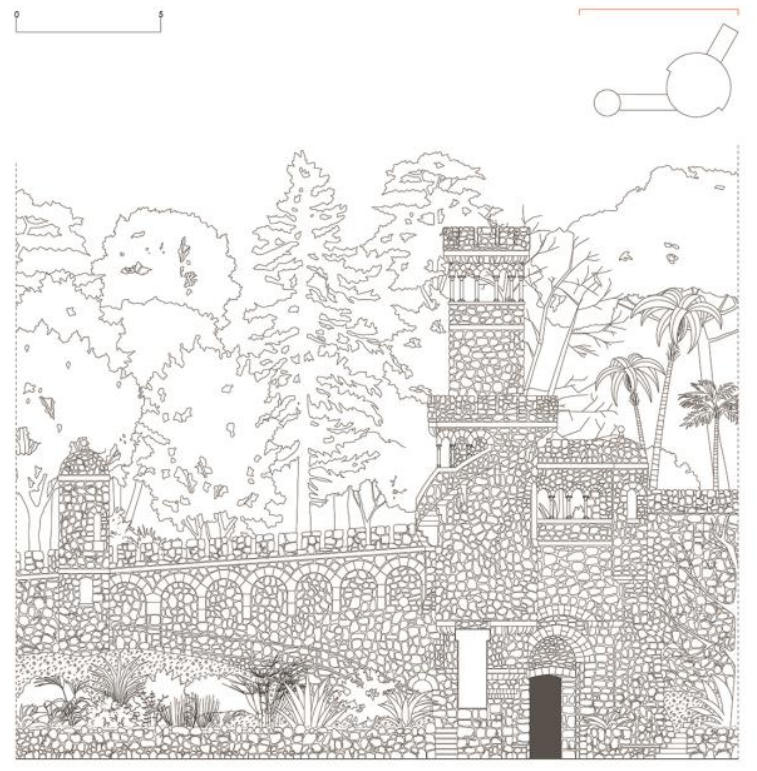

Figure 1. The Quinta da Regaleira in Sintra, the Torre da Regaleira and the Gruta da Leda, main prospect.

\section{THE SURVEY OF ARCHITECTURE}

The activity of surveying and analysing the architecture highlighted some peculiarities and gave rise to new reflections, since the structures, as well as the internal and external stairs, had never been subjected to a geometric survey. This graphic activity made it possible to observe the epigean and hypogean organisms in order to derive interesting aspects for rereading the construction phases of the architectural and vegetation complex. The survey, carried out critically using the consolidated methodologies of the discipline of drawing and the modern aids of advanced technologies for representation, aroused considerable interest in a digital vision aimed at virtualising the architecture. The analysis carried out on the vertical connections was of considerable interest given the twofold architectural component: epigeal, which develops following the course of the hill, characterised by a clear influence of different styles that blend together from Gothic to Renaissance, and hypogeal, with underground routes and relationships with the landscape. The underground of the Quinta da Regaleira in Sintra constitutes the true representative soul of the Park, consisting of a system of tunnels and stairways connecting caves, wells and water reservoirs of great architectural and structural charm. The survey activity was carried out using consolidated methodologies and innovative technological ideas, implemented through graphic and instrumental activities. Photographic surveys were carried out in order to document the current state, as well as zenithal images and views from above through the use of a four-person drone with a high-resolution camera. For the representation of plans, elevations and sections of the underground stairways, we experimented with flying in tunnels with digital films and photographic images taken in the underground routes by means of a drone with remote satellite control through predetermined spatial coordinates.

\section{THE VERTICAL EPIGEAN CONNECTIONS}

The survey of epigean architecture considered the following: the Casa da Renasceça, the Capela, the Cocheiras, the Estufa, the Oficina das Artes, the Loggia dos Pisoes, the Casa dos Ibis, the Torre da Regaleira, the Terraço dos Mundos Celestes and the Fonte da Abundância.

The Chocheiras, the current seat of the ticket office, presents itself as a formal re-proposal of the first project of the Quinta da Regaleira Palace by Manini, in a play of autonomous volumes, with a tower rising above the different architectural volumes. Over the years, this architectural complex represented the productive area of the Park, easily accessible from the outside through the large gate that connects the building to the street. The ground floor has different rooms designed to house horses, cattle and goats, as evidenced by some sculptural decorations representing animals as well as stone mangers still present.

High buttresses encircled by pinnacles divide the basement part of the building into bands, giving an impression of the subdivision of the interior spaces from the outside.

The right side of the ground floor is dominated by a portico, formed by three columns and as many round arches, preluding an entrance and inviting access. A stone staircase with 17 steps leads to a large terrace. The upper part of the building has undergone several refurbishments and now houses some offices.

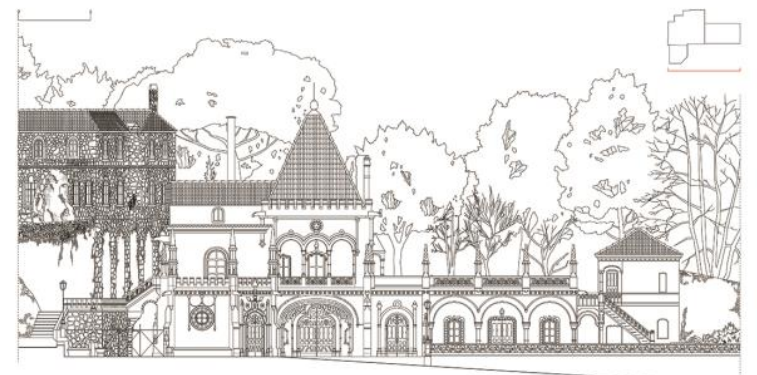

Figure 2. The Quinta da Regaleira in Sintra, the Chocheiras, main prospect.

The Loggia dos Pisoes, located at the far end of the eastern perimeter and connected to the Palácio by a wide avenue adorned with mythological statues, marks one of the entrances to the Quinta da Regaleira. It is a very common type of architectural structure in the history of gardens and is built on two levels. Two gates characterise the base of the Loggia: one in wrought iron centred in a light-coloured stone frame, and another walled in, whose symbolism implies that there is no longer any access to the lower world, surmounted by a rich decoration.

Beyond the gate is a staircase 1.28 metres wide with eleven steps. A decoration made of typical Portuguese azulejos, white tiles painted blue, depicting noblemen in a hunting scene, covers the three walls that make up the stairwell and leads to the upper floor of the Loggia. The latter has seven pairs of neoMauneline columns topped by a roof divided into three squares by ribs. This colonnade is followed by a richly decorated volume, higher than the previous part, surmounted by battlements enclosed by four pinnacles. 


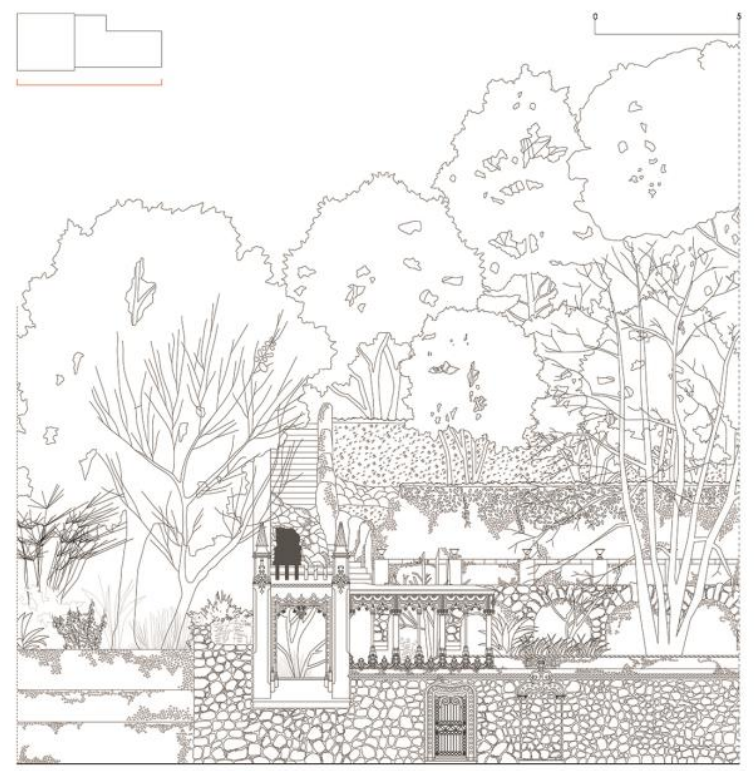

Figure 3. The Quinta da Regaleira in Sintra, the Loggia dos Pisoes, main prospect.

The Torre da Regaleira is one of the Park's most daring structures. From the first project, the architectural complexity takes on a fascinating volumetric and geometric play. The Tower, built entirely of stone, is presented as a structure organised on three levels. On the base level we find a large underground room, the Gruta da Leda, with characteristics of a ritual place, configuring a uterine space of initiation. This cave constitutes a meeting place, where the statue of the divinity is framed by a spring of water. The central floor of the tower is characterised by a colonnaded overlook from which it is possible to admire the entire park and the city of Sintra. On the left, there is a watchtower, while on the right, there is a circular room whose entrance is surmounted by a stone shield that alludes to the virtual qualities of the future knight. A staircase winds around the base of the tower and leads to the third level: a watchtower on two floors, characterised by the presence of twelve small columns and battlements at the top. It is possible to relate this tripartite structure to three planes of manifestation: the plane of conception, the plane of action in the world and the spiritual plane.

In the central part of the Quinta da Regaleira we find the Terraço dos Mundos Celestes, an epigean structure supported by six barbicans, which functioned as a cover for the cistern below. The system has a floor of rectangular limestone slabs laid in a herringbone pattern and bordered by merlons. At the two opposite vertices are two turrets, also made of stone, which serve as lookouts. The geometries of the two elements are characterised by different dimensions and a lower height of the structure on the left. A staircase with twelve steps runs along the short side of the terrace and allows one to climb to the upper part of the tower, characterised by an opening on each side and a small four-pitch roof. The largest tower, on the other hand, located on the right-hand vertex, has four superimposed levels and is called a zigurat. The basement is characterised by the presence of two round arches and two small openings near a door leading to the cistern. A staircase leads to the first level, bordered by battlements, and a narrow spiral staircase leads to the second level of irregular shape. A final spiral staircase accompanies you to the top of the tower where you can admire the impressive panorama that surrounds the entire Quinta da Regaleira complex.

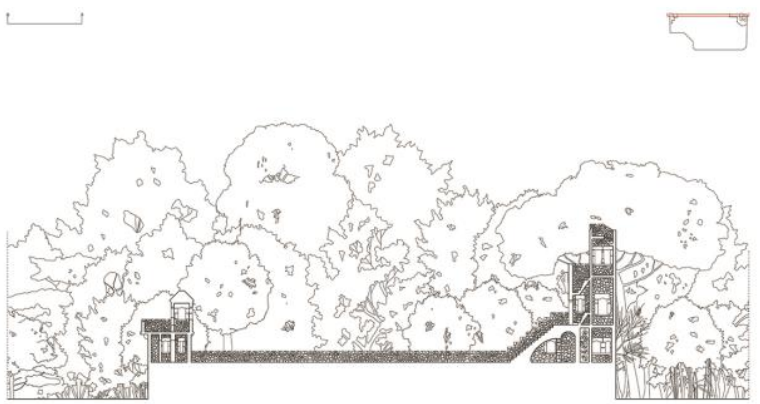

Figure 4. The Quinta da Regaleira in Sintra, the Terraço dos Mundos Celestes, cross section.

\section{THE VERTICAL UNDERGROUND CONNECTIONS}

The survey of underground architecture considered the following architectures: the Gruta do Labirinto, the Gruta da Leda, the Lago da Cascata, the Gruta do Aquario, the Gruta do Oriente, the Portal dos Guardiães, the Poço Imperfeito and the Poço Iniziático.

The Gruta do Labirinto takes its name from a series of tunnels and caves, carved into the rock, with underground passages and winding staircases that follow one another in total darkness. It is characterised by a fusion of water and stone: the lake in front enters the interior, creating suggestive spaces in the irregularly shaped plan, which stretches 17 metres longitudinally and 6 metres transversely. The underground system is characterised by a cave entrance surmounted by stone stalactites illuminated by the reflection of natural light in the water. The main prospect, located on the south side, has five irregularly shaped arches of various sizes, through which one can see the interweaving of the stairs connecting the epigean floor.

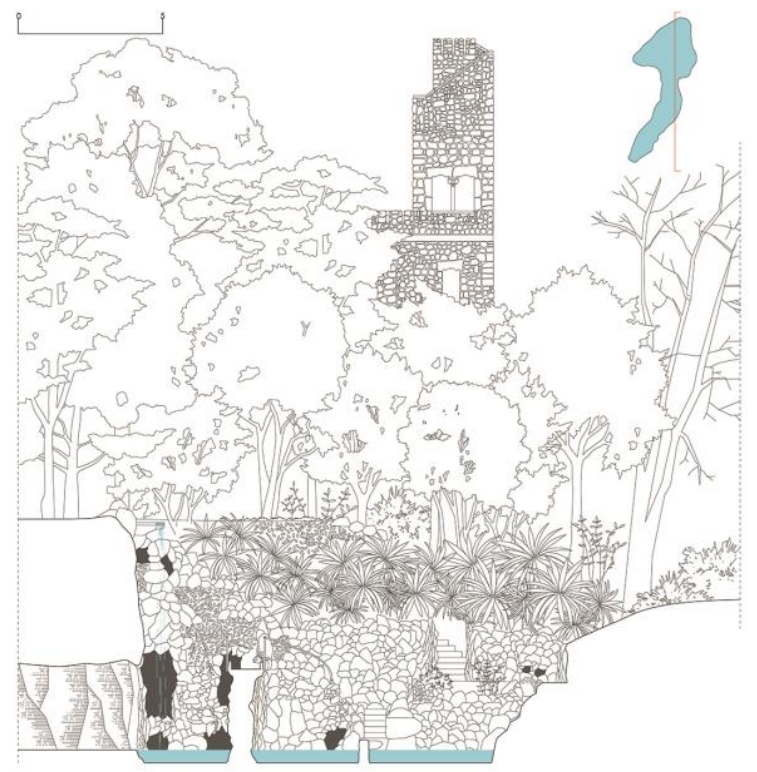

Figure 5. The Quinta da Regaleira in Sintra, the Lago da Cascata, cross section.

The Lago da Cascata is the second of the direct accesses to the underground galleries of the Quinta da Regaleira. The complex appears surrounded by vegetation and half-hidden by the water curtain of an artificial waterfall with a total height of 8 metres. The stretch of water can be crossed by walking over fifteen flat stones that emerge from the surface of the lake. The impressive 
path consists of several stairs, each with a rise of 0.20 metres and a step of 0.30 metres, leading from the shore to the highest part of the waterfall.

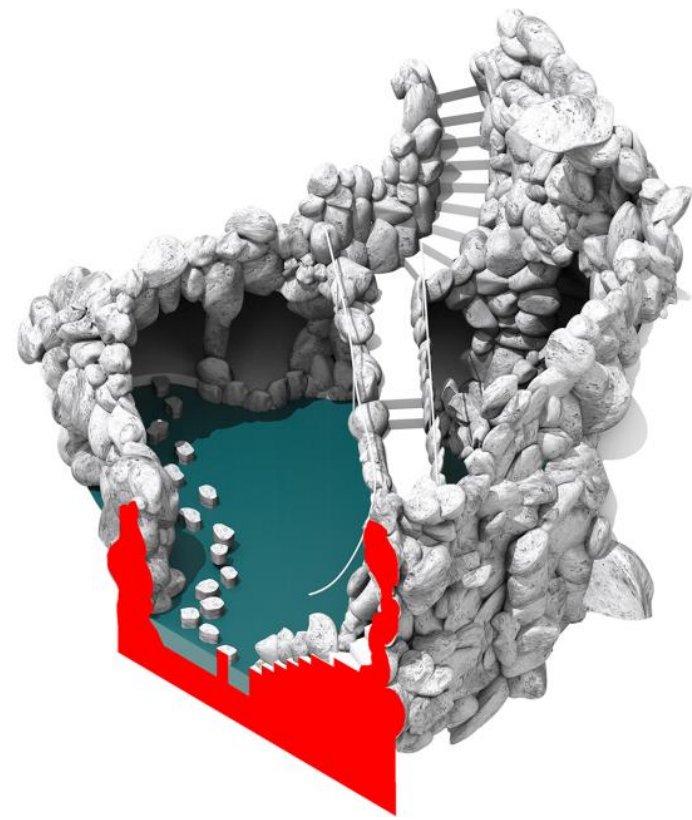

Figure 6. The Quinta da Regaleira in Sintra, the Lago da Cascata, sectioned digital model.

The Gruta do Aquário is located to the east of the Quinta da Regaleira, adjacent to the walls that surround the entire natural complex. It consists of an aquarium set into the rock, with a height of 8.55 metres and characterised by two entrances located at different heights: the upper entrance, facing south, is 2.55 metres high and 1.22 metres wide. The overhang of the ground is compensated for by a spiral staircase with a diameter of 1.65 metres, consisting of 21 steps each with a rise of 0.20 metres. On reaching the lower floor, one arrives at the interior of the cave, whose north-facing wall has two holes emerging from the rock, with a glazed view of the inside of the aquarium. The tank has an irregular shape, measuring 4.40 metres longitudinally and 1 metre transversely with a depth of 2.10 metres.

The Gruta do Oriente is one of the entrances to the underground tunnels of the Quinta da Regaleira. Its symbolic link with Dante's Hell is underlined by the two benches sculpted near the entrance, called Dante's seat and Beatrice's seat. The southfacing plan is irregular in shape, being a concavity carved entirely out of the rock. Geometrically it has a maximum diameter of 7 metres and is part of a complex system of connections consisting of stairs, tunnels and paths. A staircase, consisting of 6 steps each 0.20 metres high, connects the Gruta do Oriente with the Gruta al Patamar do Ténis, an underground structure in front of it. Laterally, two distinct secondary routes connect the first, to the east, leads to the Gruta do Aquário, along a long staircase, necessary to compensate for the considerable difference in height between the two underground structures, and the second, to the west, leads to Lago da Cascata. The main façade has three large arches made of large rocks of porous material. The first opening, on the left, is the largest with a height of 3.40 metres and a width of 2.22 metres and is the entrance to the cave.

The Portal dos Guardiaes runs from east to west, 24 metres long, and consists of an elongated, concave pavilion surrounded by stone battlements, with two towers on either side. The structure on the left has a water basin inside, symbolising the act of purification, while the one on the right has a spiral staircase with 31 steps, each with a rise of 20 centimetres and a tread of 38 centimetres. On the upper floor, in the middle, there is a hemispherical dome supported by 6 columns, above a marble altar. The entrance to the Portal dos Guardiaes consists of an arch with shell-shaped jambs and is surrounded by two statues of fantastic beings, hybrids representing the primordial kingdom from which the first forms of life emerged. From inside the portal, you access a tunnel that leads to the Poço Iniciatico.

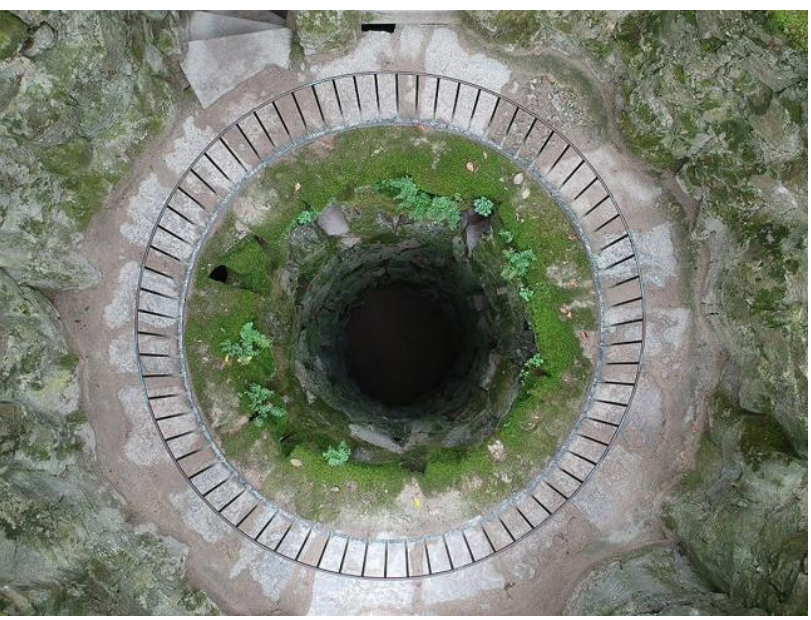

Figure 7. The Quinta da Regaleira in Sintra, the Poço Imperfeito, drone image.

The Poço Imperfeito, commonly referred to as the inverted tower, is located in the southern part of the Quinta da Regaleira, and is one of the passages to the underground complex of caves and caverns.

The upper entrance is hidden by the thick vegetation and consists of a circular row of stones, 2 metres high and with a diameter of 5 . The geometric structure consists of a perforated cylinder, with a rustic appearance, and composed of walls covered with irregular stones. The circular plan has a diameter of 2.60 metres and a depth of 8.90 metres, for a total of 5 floors, connected by two helical staircases, placed on opposite sides and hidden by the stone walls, through which it is possible to reach the bottom of the shaft, where there is a tunnel that connects the underground routes.

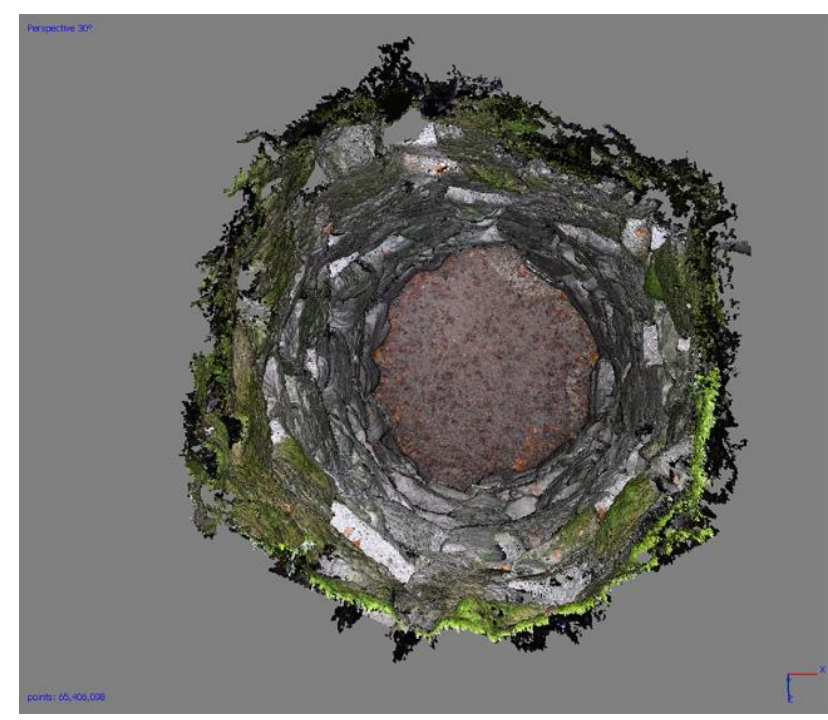

Figure 8. The Quinta da Regaleira in Sintra, the Poço Imperfeito, point cloud created by drone photogrammetry. 


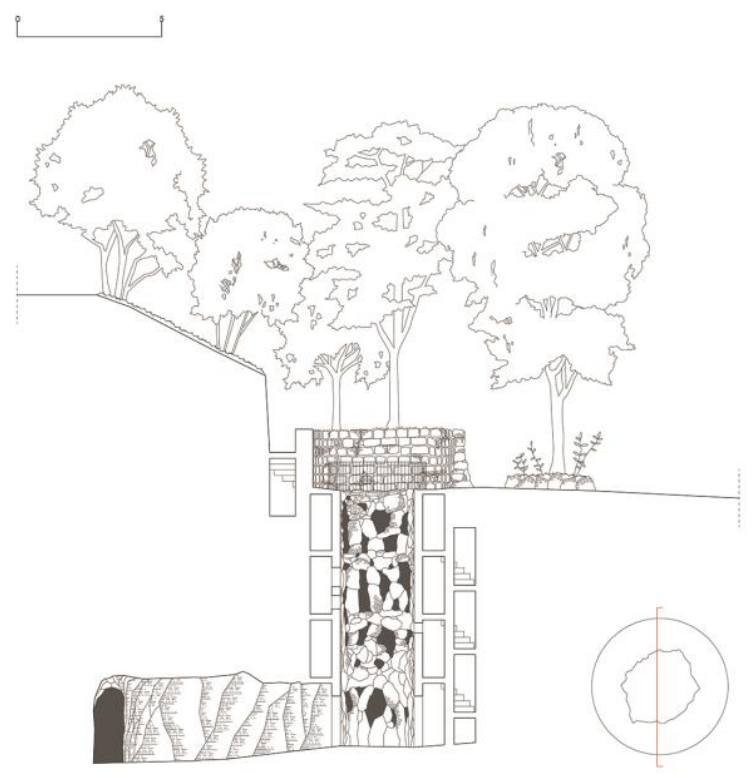

Figure 9. The Quinta da Regaleira in Sintra, the Poço Imperfeito, cross section.

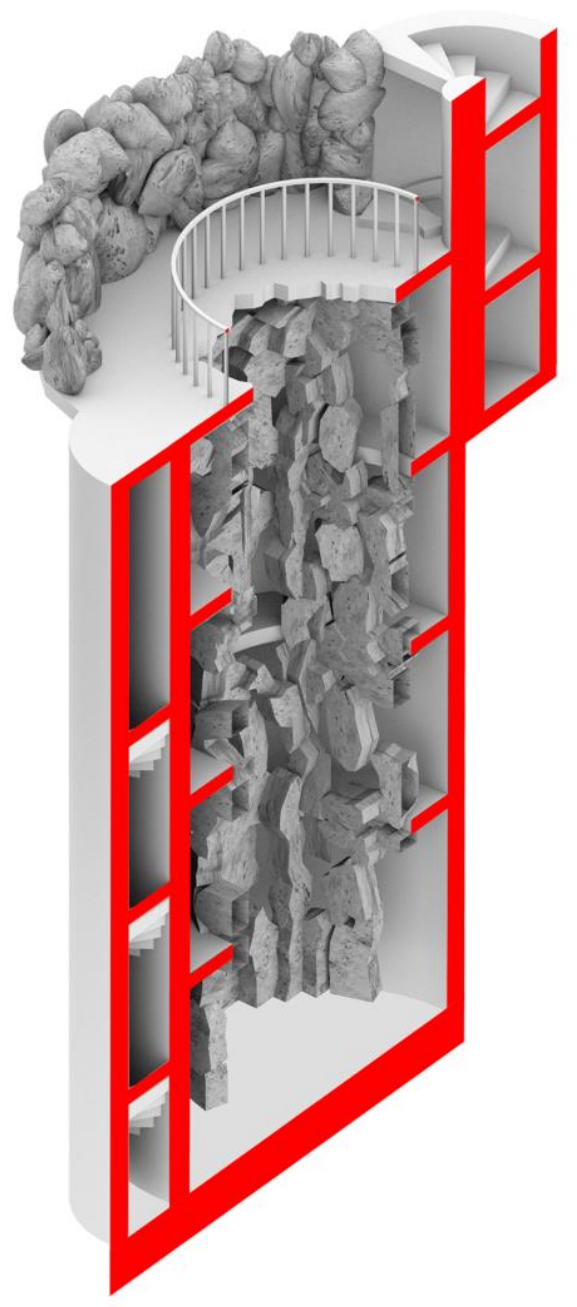

Figure 10. The Quinta da Regaleira in Sintra, the Poço Imperfeito, model cross section.
The structural conformation follows a modular development, starting from the bottom, the north stairs are the same for each floor, consisting of 11 steps each with a rise of 0.20 metres and a tread of 0.40 metres, with a floor thickness of 0.20 metres.

The staircase on the surface is the only one that does not follow the module, in fact, it consists of 10 steps, and also has the peculiarity of not being connected to an upper floor, representing incomplete architecture, a term from which the hypogeum complex takes its name.

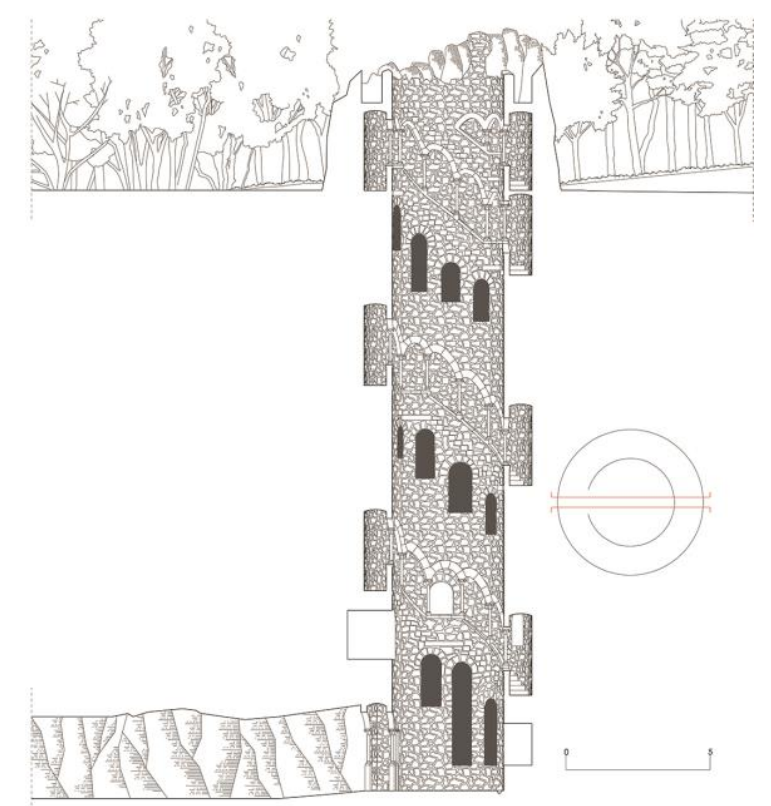

Figure 11. The Quinta da Regaleira in Sintra, the Poço Iniciatico, cross section.

Finally, the Poço Iniciatico constitutes the extreme summit of the system of underground routes, representing the meeting place of the horizontal axis with the vertical axis of the Quinta da Regaleira. The lower entrance is characterised by a round arch resting on four columns surmounted by capitals with anthropomorphic and phytomorphic figures; on the left is a fountain, recalling the act of purification. It has a circular plan with a diameter of 3.80 metres and a vertical development of 27 metres, composed of 9 levels, as many as the circles of hell, culminating, at the bottom, with a marble rose window depicting an eight-pointed star generated by a compass rose surmounted by a Templar cross. The vertical underground cavity is bordered by an enormous spiral staircase with a shaft system and pilasters, with 22 niches and 139 steps. The entire length of the interior surface is characterised by a parapet with a height of 0.70 metres, on which stand 1.20 metre high columns with capitals, on which the weight of the rampant arches rest. The eighth level is the surface exit level, with an entrance consisting of three round arches. The ninth and last level, on the other hand, crowns the entire construction: it is entirely surrounded by huge stones with the purpose of concealing the underground architecture.

\section{THE DIGITAL MODELS OF ARCHITECTURES AND CONNECTION SYSTEMS}

The digital modelling and visualisation by means of innovative software is necessary for documenting and enhancing the charm of the architecture in the Quinta da Regaleira in Sintra, starting from digital images at different scales and from acquisitions with low-cost instruments has recently obtained great scientific 


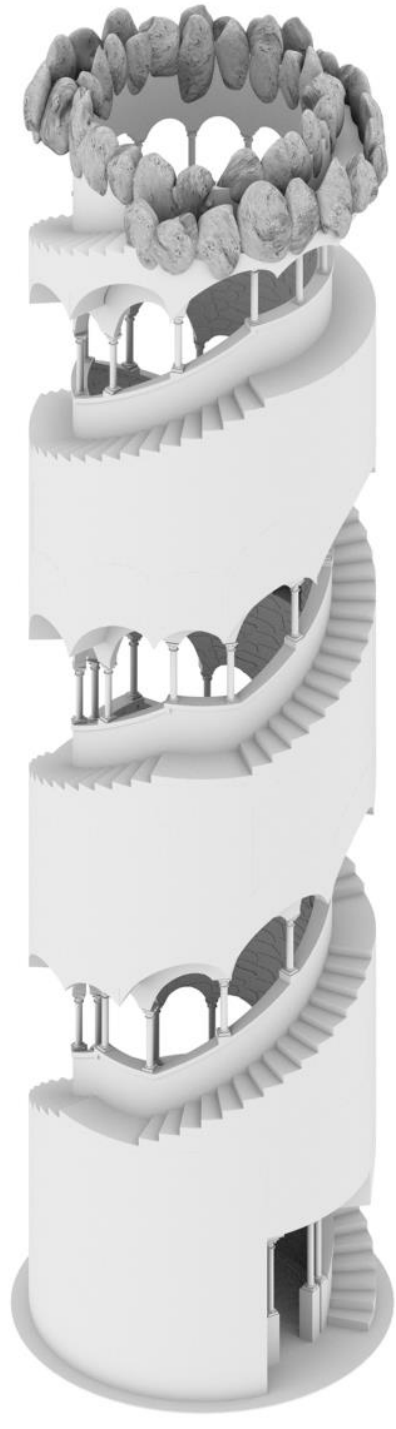

Figure 12. The Quinta da Regaleira in Sintra, the Poço Iniciatico, digital model of the staircase and structures.

attention, for the realisation of advanced digital modelling processes. In order to develop three-dimensional models for documentary purposes, it is necessary for the final product to include certain characteristics, such as precision and reliability of details, especially in areas of discontinuity, to ensure realistic restitution at close range. As is well known, the drawing of architecture, that is the practice oriented to model the object as a form, covers the main critical and theoretical exercise of method for digital technologies defining the questions of geometric nature necessary for the creation of virtual models. These models, appropriately processed and rendered with the use of specific software, have the objective of verifying the integration of the survey techniques. (Bertocci, Parrinello, 2015)

The digital representation, as well as the implicit creation of models, besides covering a graphic role of three-dimensional reproduction of the object, is a tool for checking the congruence of conventional representations, such as plans, sections and elevations. This activity was applied to the vertical connection systems, since the scales represent an element of considerable geometric descriptive value of the Park's architecture. The digital modelling is of great importance, since it allows to face,

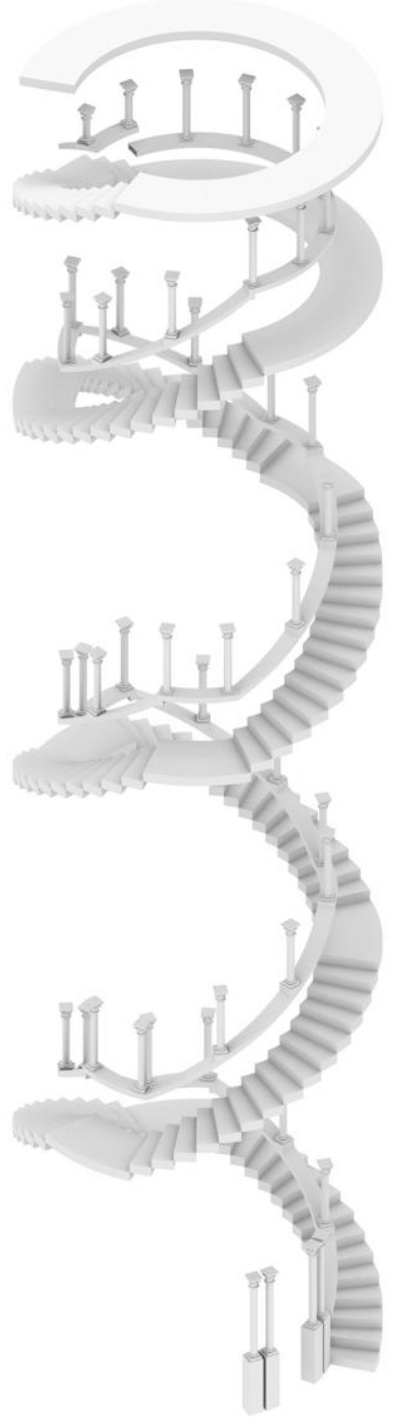

Figure 13. The Quinta da Regaleira in Sintra, the Poço Iniciatico, digital model of the staircase.

according to the technical-instrumental and theoreticalapplicative assumptions, the dynamics of the drawing related to the innovative digital representation. (Altay Açar, Bayır, 2017) This science addresses the visualisation aspect, a fundamental element for the communication of the connecting architecture in the Quinta da Regaleira in Sintra, through which it is possible to define the final graphic rendering compatible with the purpose of the survey activity, which is indicative of the protection and digital valorisation of the asset.

The new information technologies applied to geometry become a tool for restitution, analysis, information of the architectures in the Quinta da Regaleira.

The multi-resolution digital visualisation is a remarkable tool for promoting architectural and environmental artefacts that are difficult to access. (Zammel, 2019)

The construction of forms through the creation of meshes, made up of a considerable number of triangles in order to guarantee the fidelity of the virtual result with the real architecture, guarantees that a greater number of users will be able to enjoy them both at the facilities, on portable digital media, and through the digital network with interactive videos that can be viewed. 
The digital visualisation also allows the users of the Quinta da Regaleira, through the use of visors, to perceive the emotions of the past in optimal conditions, in the interior spaces dedicated to the preparation of the visit.

Subsequently understand the geometric shapes of the architecture and landscape through virtual models projected at the entrance to the structures that can be visited and, finally, select the works to be visited according to the interest of the user. (Apollonio, Amoruso, Remondino, 2010)

The digital models that can be queried thus constitute a tool for use and digital interaction between man and architecture, as well as an object for documenting the natural and man-made heritage.
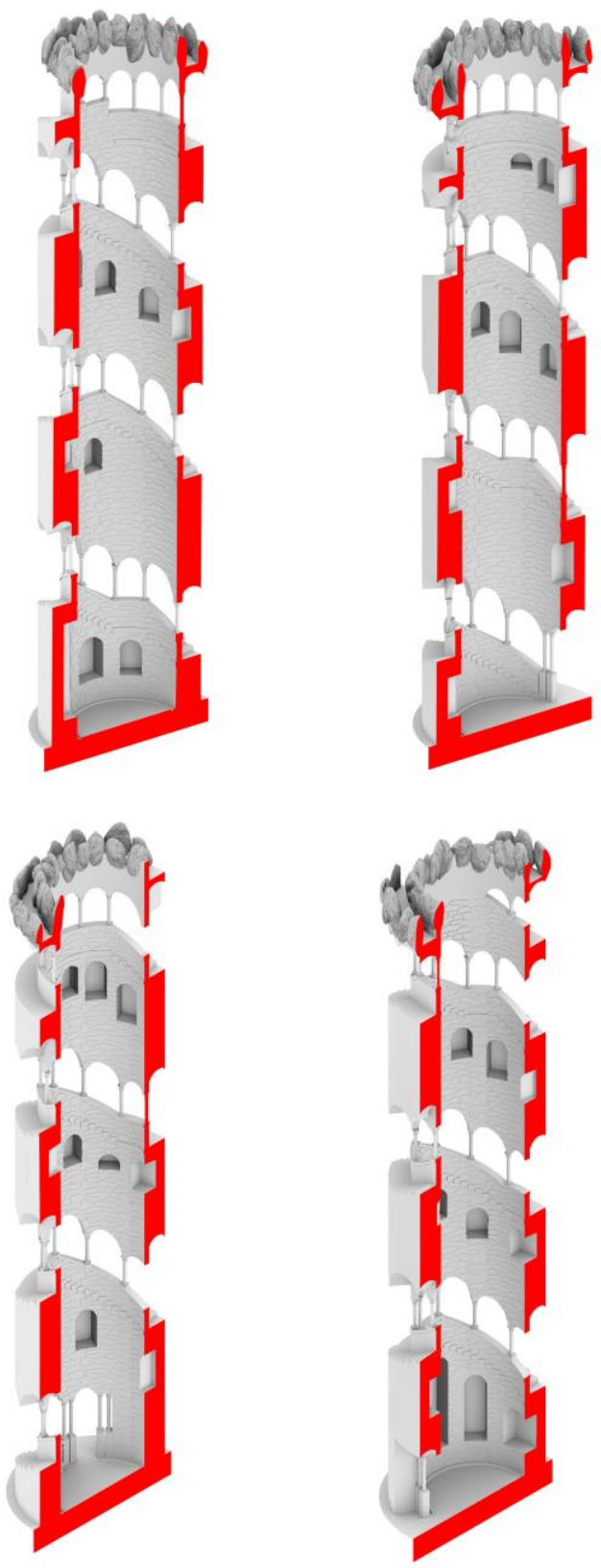

Figure 14. The Quinta da Regaleira in Sintra, the Poço Iniciatico, model cross section.

\section{CONCLUSION}

The analysis of the vertical connection systems in the Quinta da Regaleira was aimed at a complete rereading of the epigean and hypogean architectures, in their entirety and complexity, in relation to their typological and functional dimension and articulation, as well as their formal geometric dimension and articulation. A complex methodological procedure was followed: first of all, archival and iconographic documentation was carried out, followed by direct approach activities, the data acquisition phase and the relative graphic and communicative representation on an appropriate scale. The work, therefore, constitutes for the first time a complete and accurate analysis, represented through technical drawings, in different scales, digital point clouds and 3D modelling for the visualisation of the architecture in the Quinta da Regaleira in Sintra.

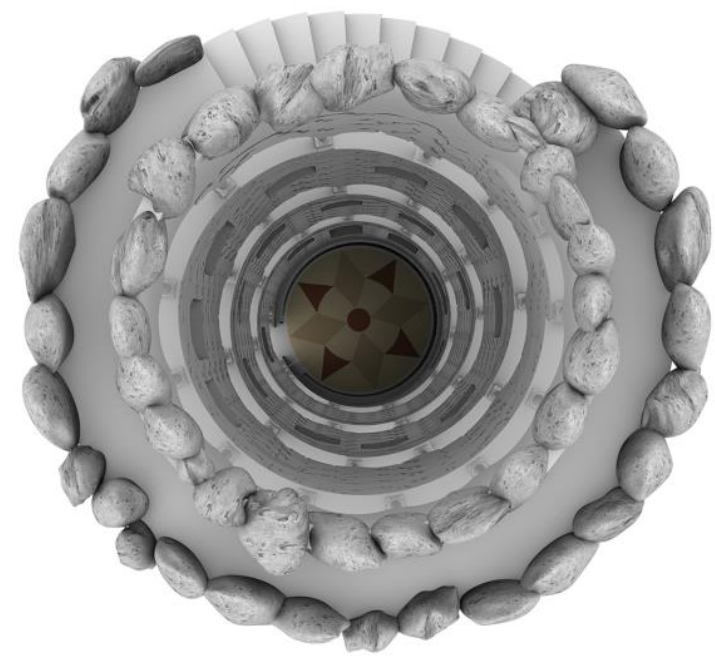

Figure 15. The Quinta da Regaleira in Sintra, the Poço Iniciatico, digital model, bird's eye view.

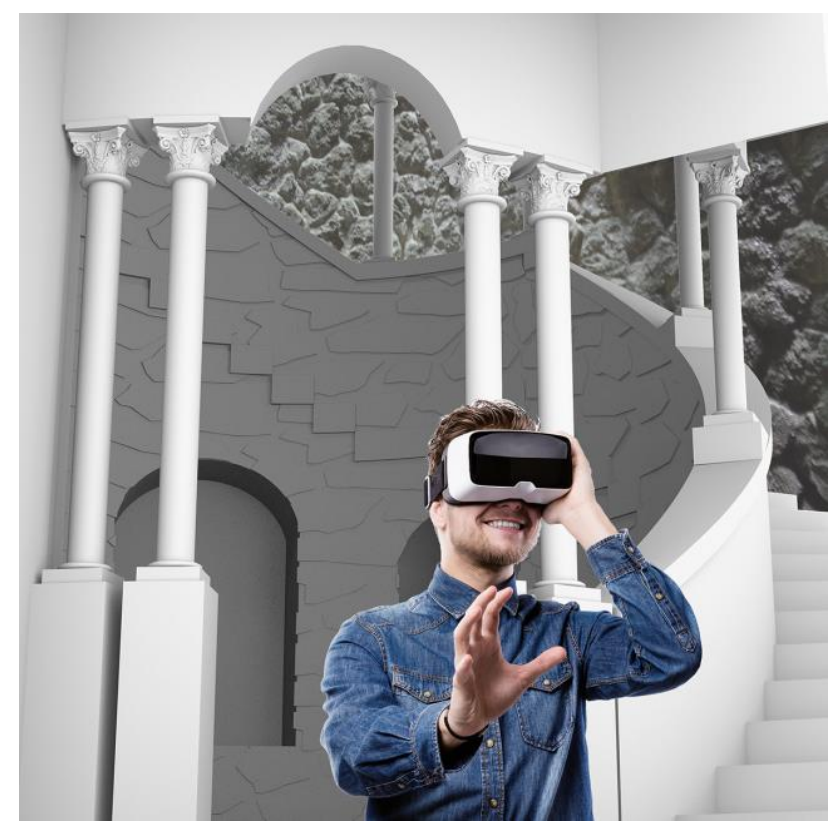

Figure 16. The Quinta da Regaleira in Sintra, the Poço Iniciatico, digital visualisation in AR for remote use of spaces. 


\section{REFERENCES}

AA. VV. 2006. Quinta da Regaleira, Luigi Manini: imaginário e método, Sintra: Fundação Cultursintra.

Altay Açar, S., Bayır, Ş. 2017, Pre-processes for urban areas detection in SAR images, Int. Arch. Photogramm. Remote Sens. Spatial Inf. Sci., XLII-4/W6.

Anes J. 2005. Os Jardins Iniciáticos da Quinta da Regaleira.

Apollonio F. I., Amoruso G., Remondino F. 2010. Caratterizzazione strumentale di sensori attivi a tempo di volo (TOF) e a triangolazione. Utilizzo di laser scanner su superfici marmoree di epoca romana, Pisa: Edizioni della Normale.

Bertocci S., Parrinello S. 2015. Digital Survey and Documentation of the Archeological and Architectural sites. UNESCO World Heritage list, Firenze: Edifir edizioni.

Cambiè A. 1936. Luigi Manini scenografo-architetto, Crema: tipografía la Moderna.

Cirillo V. 2019. Riflessioni e suggestioni fra geometria e forma. Le scale del '700 napoletano, Napoli: La scuola di Pitagora editrice.

Conte A. 2013. Memoria, Misura e Armonia come triangolazione della conoscenza, Roma, Gangemi Editore.

Cordera P. 2007. Il mestiere dell'arte. Luigi Manini e la reinterpretazione del passato tra architettura e arti decorative, Milano: Silvana Editoriale.

Corniello L. 2019. Il disegno del Parco Reale di Tirana, Napoli: La scuola di Pitagora editrice.

Corniello, L. 2020. Photogrammetric 3d information systems for the management of models of cultural heritage, Int. Arch. Photogramm. Remote Sens. Spatial Inf. Sci., XLIV-4/W1-2020.

França J. A. 2004. História da arte em Portugal. O Pombalismo e o Romantismo, Lisboa: Editorial

Giordano A. 2008. Il disegno del paesaggio: digitale $e$ tradizione a confronto, Roma: Gangemi editore.

Giordano P. 2016. Il disegno dei parchi urbani, Roma: Ermes Editore.

Gobeawan, L., Lin, E. S., Tandon, A., Yee, A. T. K., Khoo, V. H. S., Teo, S. N., Yi, S., Lim, C. W., Wong, S. T., Wise, D. J., Cheng, P., Liew, S. C., Huang, X., Li, Q. H., Teo, L. S., Fekete, G. S., Poto, M. T. 2018. Modeling trees for virtual Singapore: from data acquisition to citygml models, Int. Arch. Photogramm. Remote Sens. Spatial Inf. Sci., XLII-4/W10.

Luigini A. 2007. La rappresentazione della città. La costa pescarese, tra infrastruttura e archeologia industriale, Roma: Ed. Kappa.

Mateus, L., Ferreira, V., Aguiar, J., Pacheco, P., Ferreira, J., Mendes, C., and Silva, A. 2020. The role of $3 d$ documentation for restoration interventions. the case study of Valflores in Loures, Portugal, Int. Arch. Photogramm. Remote Sens. Spatial Inf. Sci., XLIV-M-1-2020.
Salerno R. 2017. Rappresentazione Modellazione Costruzione Digitale, Milano: Maggioli.

Zammel, M. 2019. From perspective drawing to low cost photogrammetry: application in architectural studies, Int. Arch. Photogramm. Remote Sens. Spatial Inf. Sci., XLII-2/W17.

Zerlenga O. 2018. M'illumino d'immenso, Napoli: La scuola di Pitagora editrice.

Zerlenga O., Pascariello M. I. 2014. Rappresentazione $e$ ricostruzione virtuale dell'immagine urbana, Napoli: Edizioni Scientifiche Italiane. 